\title{
How the Irish became more than white: mixed- race Irishness in historical and contemporary contexts
}

\section{Rebecca Chiyoko King-O'Riain}

To cite this article: Rebecca Chiyoko King-O'Riain (2019): How the Irish became more than white: mixed-race Irishness in historical and contemporary contexts, Journal of Ethnic and Migration Studies, DOI: 10.1080/1369183X.2019.1654156

To link to this article: https://doi.org/10.1080/1369183X.2019.1654156

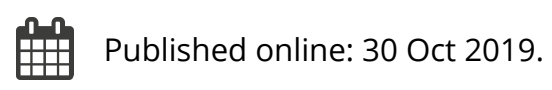

Submit your article to this journal ๘

Џll Article views: 206

Q View related articles ๘

View Crossmark data ¿

Citing articles: 5 View citing articles $\square$ 


\title{
How the Irish became more than white: mixed-race Irishness in historical and contemporary contexts
}

\author{
Rebecca Chiyoko King-O'Riain ${ }^{a, b}$ \\ aDepartment of Sociology, Maynooth University, Maynooth, Ireland; ${ }^{\mathrm{b}}$ Maynooth University Social Sciences \\ Institute, Maynooth University, Maynooth, Ireland
}

\begin{abstract}
Mixed-race people can be caught in a web of stereotypes - being pathologised as tragically 'mixed up' or heralded as the precursors of a 'rainbow nation'. Many of these stereotypes have come primarily from research and popular cultural images in the US and the UK. Recently, within Critical Mixed-Race Studies, there is a call to study mixed-race people outside of these stereotypes, particularly those living outside the US and UK. Ireland is a unique place to look at mixed-race experiences. As a post-colonial nation within Europe with a strongly racialised past (non-white to white) and a global history of emigration, Ireland is actively grappling with contemporary rapid migration and racial/ethnic change from the 2000s to today and is now possibly becoming less white. This paper examines the historical and contemporary contexts of being mixed-race in Ireland to analyse the potential political and social meanings of mixed-race Irishness today. It begins with a demographic snapshot of racial/ethnic changes in Ireland and examines the role of symbolic representations of mixed-race in Ireland. Through indicative qualitative interviews, it concludes with some tentative ideas about how understandings of mixed-race may be shifting within Ireland today.
\end{abstract}

\section{KEYWORDS}

Mixed-race; Ireland; critical mixed-race studies; Irish

\section{Introduction}

Mixed-race people are one of the fastest growing populations across the globe as more and more people identify as being more than one race (Morning 2014). This has generated a global persistence of interest in racial/ethnic difference and mixing within popular culture with historical films like Loving and contemporary films like Get Out garnering significant interest in 2017 as well as the marriage of Prince Harry in the United Kingdom to mixedrace actress Meghan Markle in 2018.

The continuing popular interest in mixed-race experiences within both positive and negative stereotypes has come primarily from research in the US and the UK. However, recently, within Critical Mixed-Race Studies, we see a call to better understand mixedrace people outside of these stereotypes, particularly those living outside the US and the UK (Daniel et al. 2014; Edwards et al. 2012; Chito Childs 2014; Irastorza, Osanami Törngren, and Song 2016; Rodríguez-García 2015; see also the Introduction by Osanami Törngren, Irastorza, and Rodríguez-García 2019, in this volume). 
The call to globalise Critical Mixed-Race Studies (CMRS) (King-O'Riain et al. 2014) recognises that the local social context is of crucial importance in shaping how historical experiences and social institutions come to shape the experiences, even the very definition, of who counts as mixed. Global studies of mixed experiences are thankfully expanding now across the world, including previously neglected places like the former Italian colony in East Africa of Eritrea (Pesarini 2015) and mixed-race in East Asia and Aboriginals in New Zealand. Ireland provides an interesting addition to the globalising of CMRS as a case of a post-colonial social context with a long history of racialisation (as non-white and then accomplished whiteness). It offers an almost unique opportunity in which to examine mixed-race lived experiences of identity processes and a possible growing social acceptance of racial difference as rapid demographic shifts, including increasing racial/ethnic diversity and interracial relationships, are happening in Ireland.

\section{Ireland's unique place in the 'White Atlantic'}

\section{Irishness in the US}

Ireland is interesting as a post-colonial nation within Europe now located politically, economically and socially between 'Boston (US) and Berlin (EU)'. ${ }^{1}$ Steve Garner (2004) explains the role of racialisation in the historical Irish experience both in the US and the UK. This history highlights the unique position of Ireland within the 'White Atlantic'. The Irish, as a diasporic group, have used 'race' as a way to separate and protect themselves in the countries to which they emigrated (primarily from other non-white immigrants, such as African Americans in the US). ${ }^{2}$ They then utilised some of these conceptions of this new found 'whiteness' in the Irish cultural nationalist movement which helped to establish Ireland as an independent, Irish and predominantly white, nation in the early $1920 \mathrm{~s}$.

Steve Garner writes in his book, Racism in the Irish Experience (2004), that the Irish in the US were racialised upon their arrival in the nineteenth century as Catholic, and therefore 'uncivilised'. All of this was occurring within a time of increasing interest in race and intelligence i.e. phrenology and scientific racism. Within this framework, Irish Catholics were viewed as non-modern, with a loyalty to Rome, and the Pope, over the nation (US), with a propensity for idleness, political corruptibility, and external allegiances. As a culturally barbarous group, the Irish were often lumped with African Americans and the comparison with blacks went so far as to consider them a Celtic tribe of 'dark' or possibly African origin (see also: Carlin 1984 or Curtis 1971). In antebellum US society, the Irish were considered 'low-browed, savage, grovelling, bestial, lazy, wild, simian, and sensual', terms almost identical to those describing blacks (Garner 2004, 133). Politically and socially they were scapegoated and oppressed in racial terms. An example of this appeared in the political satire of Puck magazine Figure 1.

In order to move from non-white to white, Garner (2004) argues that the Irish in the US learned to create an 'Irish race' that tied the diaspora to the homeland in a way that eliminated time and space - instead basing itself on notions of exile, Catholicism, and ancestry or bloodlines linked to the homeland of Ireland. They overcame racialising discrimination in order to succeed economically and politically in the US, but they did so by playing on their racial privilege of the ability to claim whiteness in the US through connections to institutions such as the Democratic party and their right to vote and own property because they 


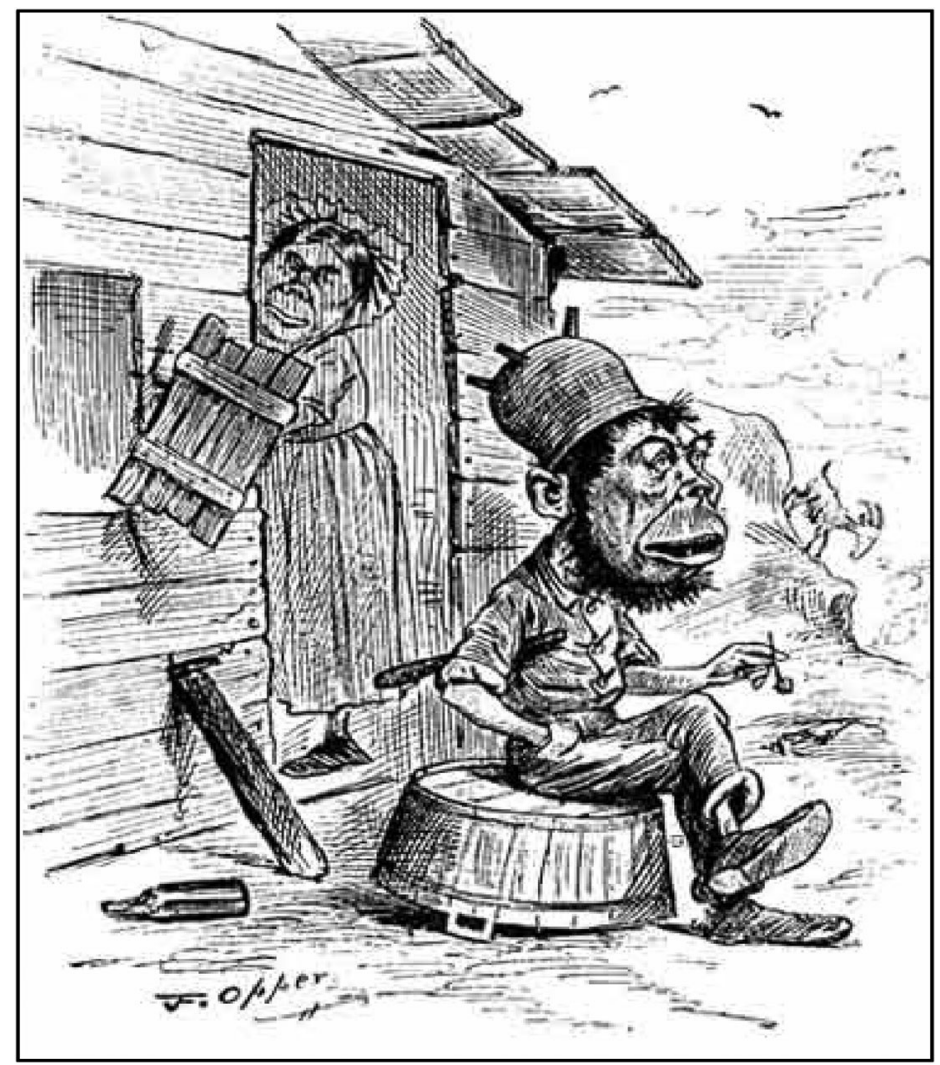

Figure 1. In Frederick B. Opper's cartoon for Puck, (1882) titled The King of A-Shantee, Paddy and Bridget are portrayed as the stereotypical Irish peasant couple, living in their lowly shanty; the Irishman is connected through the pun of 'A-Shantee' with the African Ashanti, just as his prognathous, simian features suggest that he may be the theorised 'missing link' in the evolution between apes and black Africans (from Cheng 1995, 40).

were white. This new-found sense of whiteness was also used in the cultural nationalist movement in Ireland to create a new, clearly white, nation at home in Ireland. However, even while this process was going on, we know there were interracial relationships and contact between Irish immigrants in the US and African Americans (Barack Obama's Irish ancestry) and empathy by many Irish people (in Daniel O'Connell's petition to abolish slavery signed by many in Ireland) with the plight of African Americans in the US.

\section{Irishness in the UK}

From a British colonial perspective, the simianisation of the Irish was part of the racialised discourse used to describe the Irish. On an 1860 visit to Sligo, a troubled Charles Kingsley wrote:

I am haunted by the human chimpanzees I saw along that hundred miles of horrible country. I don't believe they are our fault. I believe ... that they are happier, better, more comfortably fed and lodged under our rule than they ever were. But to see white chimpanzees is dreadful; 
if they were black, one would not feel it so much, but their skins, except where tanned by exposure, are as white as ours. (Duffy 2007, 25)

As Mary Hickman (1998) explains, the Irish in the UK, were traditionally discriminated against as Catholic, as an underclass, and as a flexible and moveable labour force on which Britain's industrial development was based. People in the UK often saw the Irish as having a propensity for fighting, drinking and low morals as exacerbated by their Popish religion and inferior cultural background.

While recent Irish immigrants to Britain have managed to escape the 'suspect community' (Hillyard 1993) status of being potential terrorists prevalent in the 1970s and 1980s, Ryan and Kurdi $(2015,269)$ found that even recent highly qualified Irish immigrants to Britain were surprised by ongoing anti-Irish sentiment and negative stereotyping in the UK. Irish people in the UK still face discrimination, but their status as 'white' now pales in comparison with visible minorities in the UK and they can be overlooked when it comes to being victims of racism. Hickman (1998) argues that this is in part due to the black/white racial paradigm in the UK where the Irish are on the 'white' side of this divide.

There has been differential treatment of the Irish historically in the UK; i.e. fewer to no immigration controls on Irish as there have been on other groups. In sum, the Irish, were seen as culturally more compatible when immigration controls came in in 1962. But even though the Irish in the UK were assumed to be culturally homogenous and the same as British, they were not. They were constructed racially as inferior and alien (Catholic).

The legacy of post-colonial racialisation by the British of the Irish could mean that Irish people are more apt to identify with visible minorities and others who also have been racialised in the not so distant past. This might mean that empathy with other racialised and formerly colonised people could mean that Irish people were more open to interracial marriage and mixed-race people within contemporary Ireland. As Robbie McVeigh (1996) writes:

Irish people's experience of many of the most terrible consequences of colonialism-genocide, slavery, starvation-have predisposed them to identify with other survivors of colonialism. Their own experience of anti-Irish racism means that there is an affinity with people who experience other racisms. It encourages people to engage with racism in terms of solidarity rather than guilt. (40)

But this isn't always the case in terms of the acceptance or recognition of racial and ethnic minorities or of mixed-race people in Ireland (north or south).

\section{Racism at home in Ireland}

Historically, there is plenty of evidence that there has been racism and xenophobia not only of the Irish abroad, but also of minority populations in Ireland (Lentin and McVeigh 2006). The emergence of Irish racial thinking about others is not a new concept. Bryan Fanning shows us the long history of persistent racism both individually and institutionally in Ireland (2002) and how it was implicated in the founding of the state on whiteness.

There is a long history in Ireland of anti-Semitism including a pogrom in Limerick in early 1900s and ongoing and persistent anti-Traveller racism (Fanning 2002). Older 
racism in Ireland had a paternalistic tinge to it in the collection boxes in the 1950s for the 'black babies' campaign where one adopted a black baby in Africa and raised money through Catholic charities to feed it. Even the Irish acceptance of Hungarian refugees in the 1950s was reluctant at best, and the treatment of these refugees was so poor that many of them left Ireland as soon as they were able.

With the Celtic Tiger Boom that happened in the early 2000s, many racially and ethnically diverse people came to Ireland to work and find a new life. This increased migration to Ireland, and for the first time in the history of state there were more immigrants than emigrants. This, however, prompted new forms of racism. The 'new racism' in Ireland (during the Celtic Tiger years of 2000-2008) was less paternalistic and based in large part on a fear of immigrants and visible minorities.

This was crystalised around Irish citizenship in 2004, when through popular vote, the Republic of Ireland voted to remove jus solis (birth right citizenship). Since 2004, children born in Ireland, whose parents are not Irish citizens, are not eligible for automatic citizenship, but instead, must go through the timely and often unsuccessful, citizenship naturalisation process in Ireland (King-O'Riain 2018). The campaign leading up to the citizenship referendum in 2004 drew heavily on images of pregnant Nigerian women coming to Ireland to give birth as way into Irish citizenship, many of which served to racialise the issue and alienate voters to close the gates to the "flood of immigrants" taking advantage of Irish citizenship. The removal of birth right citizenship served as a racialised contraction of rights within the state, and contemporary political concerns were squarely placed on understandings of race, which had subsequent impacts upon some mixed-race people in Ireland.

\section{The Construction of mixed-race in Ireland}

\section{Mixed-race people in Ireland: 1950s, 1980s and 2000s}

Historically mixed-race people, most of whom were black/white, in Ireland faced clear discrimination and mistreatment both individually and by the state. In fact, institutionally the history of the Irish state shows that the state itself was the complicit in the systematic discrimination against mixed-race children (particularly those who were part black) in state run mother and baby homes or orphanages in the 1950s, 1960s and 1970s, when single mothers were strongly encouraged/forced to put their mixed-race children (and sometimes themselves) into state care. ${ }^{3}$

Rosemary Adaser campaigned and spoke quite eloquently about her experiences of growing up as a mixed-race person in Ireland in this era. Within the documentary film, Ireland's forgotten mixed-race child abuse victims, she tells the story of her life within institutional state care. Born to a white Irish mother and a Ghanaian father in the 1950s, hers is a heart-rending story of emotional and physical abuse. At that time, Rosemary describes how mixed-race children in care were seen as unadoptable, illegitimate children, whose mothers were sexually promiscuous, fallen women and whose fathers were savages. These stereotypes and labels clearly convey the attitude that intimacy and marriage with non-whites was frowned upon. The mother and baby homes were like workhouses and prisons where more than other children, mixed-race children were singled out for abuse as they were seen to be filthy and dirty - the most undesirable of the undesirables. 
Much of the information on parents, even today, remains redacted by the Irish state and mixed-race children clearly got the message that they were unwanted and not Irish.

In response, Adaser and others, living in the UK, formed a support/campaign group called Mixed-race Irish in the UK, which became the main advocate group for historically mixed people in Irish institutions of that historical generation. They, along with other civil society organisations, have been key to increasing awareness and reparations for mixedrace children in Ireland. They also have contemporarily drawn increasing attention to the existence and issues of mixed-race young people today in Ireland.

Beginning in the 1980s, there were also other groups, started mainly by the white Irish mothers of mixed-race black/white Irish children in the 1980s and 1990s, who came together to provide a more positive social environment for mixed children, who often didn't know or see other mixed children in their everyday lives. Marian Tannam, the mother of mixed (white Irish/Ghanaian) children, founded Harmony - Intercultural Family Organisation in 1986. Harmony was a community-based organisation that existed in the 1980s and 1990s (until 1999) in Ireland for interracial families. The members were predominantly white Irish women who had had children with black African men and who were raising mixed children in Ireland. Different to the treatment in the mother/baby homes, these mothers kept their children with them, often with absent African fathers. Harmony then provided a much-needed safe social space for mixed-race children and their interracial parents (when present) to gain support in the face of negative attitudes towards interracial marriage, which still persists across the globe (Rodríguez-García 2015; Herman and Campbell 2012). It was also one of Ireland's first intercultural and anti-racist organisations, which campaigned for anti-racist legislation, provided intercultural events for adults and children and supported intercultural families and members.

Harmony was a group of families with much foresight, but even they could not have predicted the growing awareness of how historically mixed-race experiences within Ireland were soon to be fuelled by a huge demographic growth in mixed people within Ireland after 2000. There were always mixed people in Ireland, but the demographic changes in Ireland shows the exponential growth of people identifying as 'other, including mixed' within Ireland over the last 18 years. In large part, this awareness has been pushed by the changing demographics, which mean that young people in Ireland grow up in a much more racially mixed atmosphere than ever before.

\section{Demographics in the 2000s and beyond}

An increase in migration to Ireland in the early 2000s, along with the Celtic Tiger Boom, meant both an increase in the racial/ethnic diversity in Ireland as well as an increase in the number of people identifying as 'other, including mixed' on the census race/ethnicity question.

According to the Central Statistics Office in the 2016 Census, the fastest growing ethnic group since 2011 was 'Other including mixed background', with an annual growth of $14.7 \%$, reaching $1.5 \%$ of the total population, which in 2016 stood at 4.76 million people. ${ }^{4}$ In addition, $17.3 \%$ of the total population in the Republic of Ireland was now born outside of Ireland, coming from 180 countries. Census 2016 also showed a significant increase in the number of dual nationals. According to the 2016 Census, 'the number of 
persons with a dual Irish nationality almost doubled from 55,905 in 2011-104,784 in 2016'. Among dual Irish nationals, 66,440 persons (63.4\%) were born abroad.

In $2016,11.2 \%$ of Irish residents spoke a foreign language at home and Polish was by far the most common (as Polish nationals were the largest non-Irish national group), followed by French, Lithuanian and German. There was also an increasing religious diversity reflected (often, but not always, linked to race/ethnicity), with just $78.3 \%$ of the population listing themselves as Catholic in 2016. This can be compared with $84.2 \%$ in 2011 . This growing diversity created the push in 2018 to end the 'baptism barrier', to stop primary schools (the majority of which are Catholic) from requiring a copy of the baptismal certificate in order to enrol in a school, pushed by a growth in religious, ethnic and cultural diversity.

Lunn and Fahey (2011), using 2006 Census micro data, also found that 'In more than one quarter of young couples, those with a mean age of 30 years or less, at least one partner was of non-Irish nationality and/or non-white ethnicity'. In other words, 1 in 4 couples under 31 years of age was a mixed couple - an Irish person married to a non-Irish person and/or married to a non-white ethnic person. Further, Hannan, Roeder, and Darmody (2014) using the nationally representative survey dataset, Growing Up in Ireland, found that by 2011, there was a clear increase in mixed marriage (defined as in Lunn and Fahey's study) among Irish born natives. By 2011, Irish-born men who married non-Irish-born women were still most likely to marry someone from the UK (60\%), followed by the US (9\%), Central Europe (4.3\%) and Eastern Europe (3.9\%). Irish-born women who married a non-Irish-born man were also still most likely to marry someone from the UK (63\%), followed by the US (6.5\%), Central Europe (4.2\%) and Africa (3.8\%). They also found that $17.4 \%$ of married parents in the data were mixed couples, a larger number than parents who were both not Irish. This may represent a possible move from largely endogamous marriages by non-Irish people living in Ireland to more exogamy as they come into contact with a larger native Irish marriage pool. Among Asian/Irish mixed couples, 69.7\% had an Asian mother and an Irish father, constituting the biggest gendered racial difference.

\section{Mixed-race representation and the politics of racism}

While there have long been mixed-race Irish people both at home and abroad, in the 2000s, public discussions of mixed-race became more frequent in the Irish press and shifted away from being conversations just about black/white mixed people in response to the growing Asian/Irish mixed-race population. Mixed-race Gaelic Athletic Association (GAA) stars, such as Sean Óg Ó Halpin, Jason Sherlock and Lee Chin (all Asian or Pacific Islander/Irish mixes), have written detailed biographies, speaking openly in the Irish press about the racism they faced from fans and detractors while playing hurling and Gaelic football for their respective counties. In the music field, focus on black-white, mixedrace artists persisted and Samantha Mumba and Phil Lynott, ${ }^{5}$ were often evoked as long-standing Irish people of mixed descent and more recently mixed actress, Ruth Negga, nominated for an award for her portrayal of Mildred Loving in the film, Loving, proudly discussed being Irish, although not always made to feel as such, in press interviews. Everyday people too had their stories told in books, such as Margaret McCarthy's biographic snapshots of mixed-race people of various backgrounds in Ireland entitled, $M y$ 
Eyes Only Look Out: Experiences of Irish people of mixed race parentage (2001). The official census also recognised the growing importance of better understanding the mixed experience within Ireland and added the above 'other, including mixed' category to the census in 2006. All of this meant that mixed people today are much more visible and their negotiation of mixedness, including experiences with racism, is much more frequently included in the public discourse.

Symbolic representations of mixed-race people also increased within the highest political office in Ireland, that of our Taoiseach, or prime minister - Leo Varadkar (born to an Indian father and a white Irish mother) and who is the first openly gay, mixed-race leader of Ireland. David Mc Williams, a journalist, commenting on Leo Varadkar wrote:

Leo is gay but not too gay, he is Indian but not too Indian, he is socially left, but economically right - so he will follow their (Respectable Ireland's) social agenda without threatening their wallets. If he didn't exist they'd have to invent him. (Mc Williams 2017; italics added by author).

Within this portrayal of the Taoiseach, his mixed-raceness has almost become the least salient issue and there has been more focus on his class, educational, and privileged background than either his masculinity or racial background.

But not all the news is good and the strides made in the recognition that Irishness is not just whiteness anymore, are not happening in a global political vacuum. The European Network Against Racism (ENAR) (2017) in Ireland continues to tot up racist incidents in Ireland and widely reported incidents of racism against interracial couples and mixed-race people in 2017 (Van Ngyuen 2017).

ENAR recorded,

A total of 330 completed reports were received within the six month period between January and June 2017, representing $33 \%$ increase in reporting in comparison with the previous sixmonth period, in which 245 reports were received. Additionally, this level of reporting is significantly higher level than all previously recorded periods and shows a consistent rise since the launch of iReport.ie in July 2013.

The most numerous recorded incidents (111 in this time period) were examples of racist hate speech on-line. However, not all incidents were on-line. In one case, a white Irish father of a 10 year old mixed-race boy in a Munster national school was shocked when the school punished his son for verbal retaliation after he was the victim of a racist attack (Riegel 2017).

In 2017, we also saw the linking up of the 'Mixed-Race Irish' organisation in the UK, but with a continued focus mainly on black/white mixed-race Irish people, with mixedrace people living in Ireland - an attempt to cross what heretofore had been a large generation gap. The \#IAmIrish photo exhibit, made its Irish debut in celebration of Black History Month in October 2017 in the Axis centre in Ballymun (Dublin). Inspired by a persistent lack of representation of the Black Irish experience, Lorraine Maher launched the project \#IamIrish to celebrate mixed-race Irish people and to question the concept of 'Irishness' and what an authentic Irish identity means both at home and abroad.

Lorraine Maher collaborated with photographer Tracey Anderson to make an intimate study of the faces, lives and experiences of 24 mixed-race, predominantly black/white, Irish people. The exhibit was followed by a social media campaign and a panel discussion attended by roughly 100 people, which further served as a convivial and uplifting gathering 




Figure 2. 2018 Rose of Tralee Kirsten Mate Maher. With permission from John Drummey, Communications Manager, Rose of Tralee International Festival.

of many adult mixed-race people in Ireland of various backgrounds and interests. Throughout the discussion, one thing was clear, that some younger mixed-race people in Ireland have had different experiences compared to mixed-race people of the 1950s and 1960s who lived in industrial state-run homes. Many mixed young people today, live like many others in family homes, with both parents (of both races/ethnicities) present, and many also attend school with others who are mixed and are visible minorities. Some of these mixed people have become regular representative of Irishness itself (Figure 2).

\section{Understanding the social relations and struggles with racism of mixed- race in Ireland}

\section{Generation mix}

Within Ireland, many mixed-race young people have now lived their whole lives in Ireland with one Irish and one non-Irish parent much like the newly crowned 2018 Rose of Tralee, Kirsten Mate Maher, pictured above. Kirsten's father came from Zambia and her mother from Waterford. She is the first African/Irish Rose of Tralee and was quoted as saying,

[Ireland] is so much more accepting. We are all mixed and from different parts of the world. I know it's a bit more obvious with myself, I've curly hair and darker skin but at the end of the day we need to see past that. And realise that there is no typical Irish woman. We're all different and we come in all shapes and sizes, skin colour, freckles and no freckles. We're such a diverse community and we need to embrace that. I'm the first African-Irish Rose as far as I know and the 60th Rose of Tralee. (Kelly 2018)

However hopeful she was when she made these comments, within days of being crowned the Rose of Tralee, she was the victim of racist verbal abuse in Kilkenny while on a night out with friends. 
In order to understand the contemporary experiences of young mixed-race people, I attempted to find large qualitative data bases of interviews, but was unsuccessful, making a direct comparison with older black/white mixed people in Ireland (in the mixed-race Irish group in the UK) impossible. In the absence of a large qualitative data base of the experiences of these young people and in the absence of more refined census data (which would split mixed from other on the race/ethnicity question), I culled a handful of interviews from a prior project I did on the globalisation of love, which focused on interracial and interethnic couples (self-defined as one partner being Irish and the other not-Irish) and their families in Ireland. ${ }^{6}$ This project interviewed mixed (both straight and same-sex) couples and their children, when available, in Ireland.

The data in this article came from an ethnographic narrative interview study of 36 interviewees involved in transnational and interracial families. The interviews were conducted through English from 2010 to 2012 with same sex and heterosexual couples and families (ages 2-60) from Ireland, France, Canada, US, UK, Malaysia, India, Sri Lanka, Poland, Zimbabwe and China. Interviewees lived in Ireland in Cork, Kildare, Galway, Tipperary, Dublin and their surrounds. The interviews were digitally recorded and then transcribed. ${ }^{7}$

Out of the 36 interviews conducted as part of the previous narrative interview study, two interviewees were mixed (one half Hawaiian/white-Irish and the other half Indian/ white-Irish). One other interviewee, the white-Irish mother of three mixed children (white-Irish and Nigerian), also discussed her views on her children's experiences with racism over a 10-year span. The excerpts in this article come from those three interviews with a particular focus on the Asian/Irish mixed-race experience as possibly being different from the black/white Irish mixed-race experiences of past years. All of the interviews cited here were conducted by the author. These two mixed Asian/white Irish people in their twenties spoke with me and told me that they were predominantly raised in Ireland, and experienced discrimination and the structural limiting of their opportunities. Clearly, being black/white Irish is not the same as being Asian/Irish and so no general conclusions can be drawn from the interviews below, but it does give us a preliminary sense of the issues that arise contemporarily for some mixed young people in Ireland today as the Asian population is the second fastest growing population, after 'other including mixed' in Ireland.

Sarah, who was born in the mid-1990s and is part Hawaiian and part white-Irish, talks about the different contexts of racial acceptance in Hawaii, the continental U.S. and Ireland. Having spent half her life in the continental U.S. and half in Ireland, she explains how she sees herself.

Interviewer Do people (in Ireland) ever ask you where you are from?

Interviewee They do, all the time people ask me where I am from because even when I say America, they say, 'you don't look like you are American'. People ask me if I am Egyptian or from the Middle East or all kinds of things. I suppose because I am a bit more olive than some people so people are always asking me what am I. I think it is the Hawaiian that makes my skin so olive.

Interviewer And when they ask you, what is your response?

Interviewee I usually would say either native Hawaiian or French Polynesian, because if I just say Hawaiian it is a bit confusing because there are loads of people from Hawaii that wouldn't be Polynesian as well, so I usually say that. But it is quite funny because I have people ask me if I was half African-American and things 




There is clearly an internal tension here for Sarah as she says that Irish people don't really ask about her race, but when they do, they say she doesn't look American. Within this there seems to be a recognition by Irish people that the USA is more ethically and racially diverse than Ireland, but even within that recognition, that Americaness is still seen as predominantly synonymous with whiteness. Thus, for Sarah, even a slightly darker skin colour, makes her different and it is worthy of comment in a predominantly white identifying Ireland (for similar findings, see the interview cases presented by Rodríguez-García et al. 2019, in this volume). $82.2 \%$ of people in the 2016 Census identified as white Irish (CSO 2016a, 2016b, 2016c). So, in Ireland, once people find out that she is American, that seems to mean that because she is not Irish, that this might explain why her skin colour is darker. It is also possible in Ireland that there could also be a less finely tuned awareness of the different types of Asian Pacific Islander groups and ethnic/racial identities and thus questions about the shape of her eyes or her darker skin being linked to being part Hawaiian may not occur to Irish people as there as very few Hawaiian people living in Ireland. The quotes nicely illustrate how the salience of race can possibly change depending not upon Sarah's body or its appearance but where she is seen - either the USA or Ireland.

Ann, born in the mid-1950s, a white Irish mother of three black/white Irish mixed-children, was raised in the Caribbean as a child. She also discussed changing meanings of race between the USA, where she lived for a time, and in Ireland. She met her Nigerian husband at a college party in Ireland in the 1970s and they had their mixed-race daughters in the late 1970s. She describes the racism that her mixed daughters experienced in Ireland in the mid-1980s.

Interviewee Would you like to know that the first place that my daughter experienced racism? And maybe it is more secret there (in the U.S.) or more low-key because of laws and things like that, it was Ireland when she came back from the U.S. (Italics added by author for clarity)

Interviewer That is interesting. What age was she then?

Interviewee She came back about ... I stayed there for five years, so she was five, and she just could not ... it damaged her terribly. It made her quite an aggressive person actually and I think it changed her personality. And had I the courage I would have gone off somewhere else, but I didn't at the time. And I have three children and they have all experienced a different kind of 
racist Ireland. So ... how am I going to explain this? Because for [daughter 1] it was very different, for [daughter 2] who is a different character, there was racism but in a very different way. It was all so... she is very pretty and there was sexism, she was tortured because she was more pretty, than her colour. And then I wonder is it because both of them are quite different colours. [Daughter 1] is very, well she is very pretty now, but she is very Nigerian looking, she would take the world on. [Daughter 2] is very feminine with long curly, coily hair and fits the stereotype of a mixed girl.

Interviewer Is she more light-skinned?

Interviewee A little yes, [daughter 1] is not really dark but she is quite robust and feisty and every Nigerian friend I have says, 'God [daughter 1] is a real Nigerian'.

Ann clearly explains how she feels that different physical appearance came to shape each of her daughters for better or worse (for similar findings, see the interview cases presented by Rodríguez-García et al. 2019 in this volume). Ann also gave birth to a son 10 years later and explains how meeting other white Irish women who were mothers of mixed children in Ireland helped both her and her son to cope with changing notions of Irishness.

Interviewee She (another mother of mixed children) is grand. But I met her in church and I had never set foot in a church, and there was a choir and [daughter 1] was there, she really is an amazing person, she is only there... I suppose she saw me with black kids and she [unclear 4528 16] and she came over... because she is quite shy in comparison to me. And she introduced herself and she said...

Interviewer Is her son the same age as...

Interviewee Her son is the same age as [name], my eldest daughter, and his father was from Ghana, and she told me about, she said, 'I am involved in an organisation called Harmony...' which was a great thing as a cultural thing at the time. I don't know if it has its place anymore but certainly for my children it was fabulous.

In Ann's words, the need for a community-based group like Harmony was clear to her in the 1980s. Her mixed children were seen as black, she refers to them as black, and she explained that they needed support in order to survive and combat the racism they encountered in their daily lives. I asked her if she felt things were different 10 years later (from the 1980s to the 1990s) for her son. She explained:

Interviewee Well I think things are more dreadful than they ever were. [Son] lives a very protected life, he lives in a very, very secure middle-class background. He goes to a school with 250 pupils. He excels at the sports that he does but you put him, and this might sound, we might get into a sort of a class thing, if he sets foot into what we would term as another kind of area, the first thing he hears is ' $\mathrm{n}^{* * *}$ er'. Now I am not saying that doesn't happen ever to him (at school) but it is not said.

Interviewer It is more subtle.

Interviewee It is more subtle but he doesn't ... he says, 'I wish you wouldn't bring racism into everything because if I have a fight at school you always say it was racism, it never is'. So he doesn't feel he experiences it in that way. But certainly if he goes into a certain area and I am trying to actually get him to cop on to himself because he will reach a point where he says, 'I don't want to go into town'. But he has experienced racism.

Interviewer Even with increasing diversities? 
Interviewee Yes definitely. I will tell you what they hate him for, I can't say hate him, but they probably do, they hate him because they see him as posh as well.

(STE 16: 18).

Ann worried aloud about protecting her mixed-race son from what she saw as increasing racism. She was troubled by his experiences in both what she describes as their secure middle-class context, but also in 'another kind of area' (working class context) and she worried about her ability as a white Irish mother to teach him about and prepare him for how to identify racism. She feels that his racially mixed background is clearly a reason that may have triggered racism towards him, but class also seems to be a strong factor that shaped his experiences growing up in Ireland.

Arjun, whose mother is from Kerala, in India, and whose father was white Irish from Dublin, met in India while his father was doing volunteer work in India in the 1980s. They returned to Ireland with their 2 children; himself and his sister. His parents split up when he was 14 years old, and his father emigrated to Australia, but he describes his relationship with both of his parents as warm. He describes growing up in a Dublin suburb that people used to comment about how he was 'different'.

Interviewer And did you ever have any of those experiences where people would say things to you?

Arjun All the time.

Interviewer: Really? Give me an example.

Arjun In secondary school people would call you Paki, even though your mother is from India and Pakistan and India are like Ireland and England (at times a politically tense relationship), so it was like me calling them English. Just things like that, racial names, but like people are going to bully you over anything, whether you are big, fat, black, white, yellow, whatever so it is just something that you come to terms with. (italics added by author for clarity)

Interviewer And do you think that they were just picking up on that you just looked physically different or that your name was different, I mean I am wondering what the trigger was for people on it.

Arjun Personally, I don't think it is my name because first of all I used to go around saying, I don't like my name, it takes about half an hour for people to get the correct pronunciation. So, I don't think it is names. It is more cool to have a unique name, but I think it is just people see you different to what they are.

Interviewer Physically see you different.

Arjun Yes, and I suppose people have insecurities with themselves and then they try to take it out on you.

Interviewer And do you think it is changing at all in Ireland?

Arjun Absolutely, $100 \%$ changing, there are so many ethnicities around now and people are friends with Polish people and African people and Chinese people. I think it is changing from when I was younger because you see young kids now, before, like it wasn't too bad for me but I would say a couple of years before me, the previous generation, if there was an Indian or Anglo-Indian child in the class people would sort of avoid them. But now they are all mingling together and being friends.

From the symbolic representation of the first mixed-race Rose of Tralee, as a symbol of Irish culture and identity, we can see that for her, there is hope that it is possible that racial difference is becoming more common in Ireland today. Arjun's insistence above that everyone has something that makes them different and a possible target of bullying such as 'whether you 
are big, fat, black, white, yellow, whatever so it is just something that you come to terms with' illustrates a rationalising of racial discrimination as just one of many types of discrimination that can be experienced. However, normalising phenotypical difference (particularly skin colour), still seems to be a significant issue in mixed-race Irish young people's ability to lay claim to being both Irish and something else along with other social and demographic factors, such as gender, class or the neighbourhood where one lives.

\section{Conclusions}

It would have been almost impossible 50 years ago in Ireland to imagine a mixed-race (half black) Rose of Tralee and despite experiences of discrimination, there is growing awareness of mixed-race people both within state and individual, interpersonal notions of Irishness. For the most part, there were no complaints or public outcry that Kirsten Mate Maher didn't 'look Irish' or that she 'wasn't Irish' when she was crowned in 2018 the way there have been in other national pageants such as in Japan when Miss Universe Japan 2015, Ariana Miyamoto, who is half African-American and half Japanese, faced vocal complaints that she was not a good representative of Japan because she was mixed-race (on mixed-race experiences in Japan, see Osanami Törngren and Sato's 2019, contribution in this volume). This paper has attempted to illustrate the various ways that mixed people in both the past (predominantly in a black/white mixed-race frame) and present (in a more diverse racial frame including more Asian/Irish mixed-race people) have navigated the ambiguities of transnational and transracial linkages and Irish racialisation itself. Their experiences show that while there is some movement of Irishness to include non-white and mixed people, more significantly, the on-going constraints that they face in terms of individual and state exclusion and daily experiences of racism and rejection are not going away anytime soon and in fact, this could increase if the political and social atmosphere were to take a turn to the right as it has in the UK under Brexit and in the US under a Trump presidency.

More people in the UK and US identify as being mixed (Song 2012, 2017; Platt 2012) and this is true in Irish Census as well. However, mixed-race people in Ireland, as in many other places, see themselves neither as harbingers of a post-racial world nor as exclusively troubled souls of the past, but instead as more and more a part of the norm of the growing racial/ethnic diversity in Irish society. In addition, the growing multiracial population in Ireland has experienced the rapidly changing social, political and economic context of understandings of race and racialisation in Ireland.

Ireland is a unique place in which to look at mixed-race experiences. As a post-colonial nation within Europe with a strongly racialised past (non-white to white) and a history of emigration across the globe, it is now actively working to cope with rapid migration and growing racial/ethnic diversity at home and abroad.

By giving a demographic snapshot of racial/ethnic changes in Ireland within a historical context of post-colonial racialisation, I have tried to think about the role of symbolic representations such as the current Rose of Tralee, of mixed-race in Ireland, and of Irishness itself. This paper has also given a small glimpse into the lives of a few, mainly Asian/Irish mixed people in Ireland today. Clearly generalisations cannot be drawn from this data, but data highlights the need for much larger and more racially/ethnically (as well as gender, class and religiously) diverse samples to be interviewed in Ireland. However, there are particular insights into these experiences and as the mixed population continues to grow, it 
will be important for us to understand how being mixed is changing in contemporary Ireland and may perhaps be different from the institutional racism faced by mixed people in the 1950s.

In so doing, the paper also contributes to critical mixed-race theorising as it highlights a growing awareness of mixed-race people in Ireland and around the globe (Fozdar and Rocha 2017; see also the Introduction by Osanami Törngren, Irastorza, and RodríguezGarcía 2019, in this volume), which can problematise state and interpersonal understandings of national and culture identities (King-O'Riain et al. 2014). Specifically, it traces the Irish case through the racialisation of Irishness in the US and UK in the past century through to the 'new communities' in Ireland brought about through migration (Lentin and McVeigh 2006). Growing racial and ethnic diversity in Ireland means that we must now think about how diversity is impacting what it means to be Irish (Fanning 2011, 2018), including what it means to be mixed-race and Irish today. The very presence of mixed-race bodies in Ireland and their willingness to identify as mixed, can have the potential to radically shift racialised notions of Irishness away from being equivalent to whiteness to possibly incorporate non-whiteness into the mix.

\section{Notes}

1. In July 2000, Mary Harney, the Irish Enterprise Minister, addressed the American Bar Association, famously saying, 'Geographically, we are closer to Berlin than Boston. Spiritually, we are probably a lot closer to Boston than Berlin' (see White 2011).

2. This is not to imply that race is biological, instead race is defined by Cornell and Hartmann (2007) as ' ... a human group defined by itself or others as distinct by virtue of perceived common physical characteristics ... ' (Cornell and Hartmann 2007, 25); however, the perception of those physical differences is socially constructed.

3. There is no historical evidence to show that multi-ethnic children faced the same plight, or even that there were many multi-ethnic children as most of the testimonials thus far are from black/white mixed-race children in the homes.

4. The Census has not disaggregated or analysed the 'other' category so there is no way to tell how much of this category is people who identify as 'other' and how much is 'mixed'. There also has been no qualitative analysis of the 'write in description' data.

5. A documentary about Phil Lynott entitled, Phil Lynott - Scéalta Ón Old Town, aired on RTE in December 2018 in which Lynott remarked 'When I'm in England, I'm Irish. When I'm in Ireland, I'm from Dublin. When I'm in Dublin, I'm from Crumlin' highlighting how he felt always marginalised.

6. We did not limit the sample to people born in Ireland = Irish because many ethnically Irish (and racially white) Irish people have been born in the UK, Australia, Canada and the US. In addition, many of the non-Irish partners, identified as people of colour (black, Asian, etc.) and not-Irish (in terms of citizenship), but felt they were culturally Irish. We allowed subjects to define for themselves who was Irish and who was not based on a combination of factors including place of birth, nationality, ethnicity, religion, and race.

7. The project complies with best professional ethical practice and the project was approved by the Maynooth University Ethical Approval Committee. All interviewees gave their express consent to be interviewed. Read more about the 36 interviewees in (King-O’Riain 2015).

\section{Disclosure statement}

No potential conflict of interest was reported by the author. 


\section{References}

Carlin, N. 1984. "Ireland and Natural man in 1649." In Europe and its Others, Vol. 2, edited by F. Baxter. Essex: University of Essex.

CSO (Central Statistics Office). 2016a. Census. https://www.cso.ie/en/media/csoie/census/ census2016/2016censusforms/65995_English_Household_2016_New_Version_Do_Not_ Complete.pdf.

CSO (Central Statistics Office). 2016b. Census of Population 2016 - Profile 7 Migration and Diversity. https://www.cso.ie/en/releasesandpublications/ep/p-cp7md/p7md/p7dn/.

CSO (Central Statistics Office). 2016c. Census of Population 2016 - Profile 8 IrishTravellers, Ethnicity and Religion. http://www.cso.ie/en/releasesandpublications/ep/p-cp8iter/p8iter/p8e/.

Cheng, V. J. 1995. Joyce, Race and Empire. Cambridge: Cambridge University Press.

Chito Childs, E. 2014. "A Global Look at Mixing: Problems, Pitfalls and Possibilities." Journal of Intercultural Studies 35 (6): 677-688.

Cornell, S., and D. Hartmann. 2007. Ethnicity and Race: Making Identities in a Changing World. Newbury Park, CA: Pine Forge Press.

Curtis, L. P., Jr. 1971. Apes and Angels. The Irishman in Victorian Caricature. Washington, DC: Smithsonian Institution Press.

Daniel, G. Reginald, L. Kina, W. M. Dariotis, and C. Fojas. 2014. "Emerging Paradigms in Critical Mixed Race Studies." Journal of Critical Mixed Race Studies 1 (1): 6-65. https://escholarship.org/ uc/item/2db5652b.

Duffy, E. 2007. "As White As Ours: Africa, Ireland, Imperial Panic, and the Effects of British Race Discourse." In Empire and After, edited by Graham MacPhee, and Prem Poddar, 25-56. New York, NY: Berghahn Books.

Edwards, R., A. Suki, C. Chamion, and M. Song, eds. 2012. International Perspectives on Racial and Ethnic Mixing and Mixedness. London: Routledge.

European Network Against Racism. 2017. http://enarireland.org/enar-irelands-january-june-2017ireport-ie-reports-of-racism-in-ireland-published/.

Fanning, B. 2002. Racism and Social Change in the Republic of Ireland. Manchester: Manchester University Press.

Fanning, B. 2011. Immigration and Social Cohesion in the Republic of Ireland. Manchester: Manchester University Press.

Fanning, B. 2018. Migration and the Making of Ireland. Dublin, Ireland: University College, Dublin Press.

Fozdar, F., and Z. L. Rocha. 2017. Mixed Race in Asia: Past, Present, and Future. London: Routledge.

Garner, S. 2004. Racism in the Irish Experience. London: Pluto Press.

Hannan, C., A. Roeder, and M. Darmody. 2014. "How Open Are the Irish? Exploring Intercultural Family Formation in Ireland." Growing Up in Ireland Conference. November 26. Croke Park, Dublin, Ireland. Accessed January 29, 2018. http://www.esri.ie/pubs/How_open_are_the_ Irish_Hannan_et_al_.pdf.

Herman, M. R., and M. E. Campbell. 2012. "I Wouldn't, but You Can: Attitudes Toward Interracial Relationships." Social Science Research 41 (2): 343-358.

Hickman, M. J. 1998. "Reconstructing Deconstructing 'Race': British Political Discourses About the Irish in Britain." Ethnic and Racial Studies 21 (2): 288-307.

Hillyard, P. 1993. Suspect Community: People's Experience of the Prevention of Terrorism Acts in Britain. London: Pluto Press.

Irastorza, N., Osanami Torngren, S., and Song, M.. 2016. "Mixed Couples, Mixed Societies? Intermarriage, Modes of Integration and Social Cohesion." Ethnicities 16 (4): 497-520.

Kelly, L. 2018. "New Rose of Tralee Kirsten Mate Maher says there's no 'typical Irish woman' any more after she's crowned winner of popular competition." The Irish Sun. August 22. https:// www.thesun.ie/tvandshowbiz/3015643/rose-of-tralee-kirsten-mate-maher-waterford-typicalirish-woman/. 
King-O'Riain, R. C. 2015. “Emotional Streaming and Transconnectivity: Skype and Emotion Practices in Transnational Families in Ireland." Global Networks 15 (2): 256-273. doi:10.1111/ glob.12072/abstract.

King-O’Riain, R. C. 2018. "What's Love Got To Do With It? Emotional Authority and State Regulation of Interracial/National Couples in Ireland." Journal of Intercultural Studies 39 (4): 494-509. doi:10.1080/07256868.2018.1484344.

King-O'Riain, R. C., S. Small, M. Mahtani, M. Song, and P. Spickard. 2014. Global Mixed Race. New York, NY: New York University Press.

Lentin, R., and R. McVeigh. 2006. After Optimism? Ireland, Racism and Globalization. Dublin, Ireland: Metro Eireann Publications.

Lunn, P., and T. Fahey. 2011. "Households and Families Structures in Ireland." Accessed January 29, 2018. https://www.esri.ie/news/households-and-family-structures-in-ireland/.

McCarthy, M. 2001. My Eyes Only Look Out: Experiences of Irish People of Mixed Race Parentage. Channel Islands: Brandon.

McVeigh, R. 1996. The Racialization of Irishness: Racism and Anti-Racism in Ireland. Belfast: Centre for Research and Documentation.

Mc Williams, D. 2017. "McGregor Embodies the New Ireland.” Irish independent 26 August 2017. https://www.pressreader.com/ireland/irish-independent/20170826/283708364569651.

Morning, A. 2014. "Multiraciality and Census Classification in Global Perspective." In Global Mixed Race, edited by R. C. King-O’Riain, S. Small, M. Mahtani, M. Song, and P. Spickard, 115. New York: New York University Press.

Osanami Törngren, S., N. Irastorza, and D. Rodríguez-García. 2019. "Understanding Multiethnic and Multiracial Experiences Globally: Towards a Conceptual Framework of Mixedness." Journal of Ethnic and Migration Studies. doi:10.1080/1369183X.2019.1654150.

Osanami Törngren, S., and Y. Sato. 2019. "Beyond Being Either-or: Identification of Multiracial and Multiethnic Japanese.” Journal of Ethnic and Migration Studies. doi:10.1080/1369183X.2019.1654155.

Pesarini, A. 2015. Colour Strategies. Negotiations of Black Mixed Race Women's Identities in Colonial and Postcolonial Italy. PhD Thesis, University of Leeds.

Platt, L. 2012. "A Descriptive Account of Those Self-Identifying as of Mixed Ethnicity in Great Britain." In International Perspectives on Racial and Ethnic Mixedness and Mixing, edited by R. Edwards, S. Ali, C. Caballero, and M. Song, 108-124. London: Routledge.

Riegel, R. 2017. “Father's 'disgust' following 'racist incident' involving son (10) in school." Irish Independent. November 22. https://www.independent.ie/irish-news/fathers-disgust-followingracist-incident-involving-son-10-in-school-36343148.html.

Rodríguez-García, D. 2015. "Introduction: Intermarriage and Integration Revisited: International Experiences and Cross-Disciplinary Approaches." The ANNALS of the American Academy of Political and Social Science 662 (1): 8-36.

Rodríguez-García, D., M. Solana, A. Ortiz, and B. Ballestín. 2019. "Blurring of Colour Lines? Ethnoracially Mixed Youth in Spain Navigating Identity." Journal of Ethnic and Migration Studies. doi:10.1080/1369183X.2019.1654157.

Ryan, L., and E. Kurdi. 2015. “'Always up for the Craic': Young Irish Professional Migrants Narrating Ambiguous Positioning in Contemporary Britain." Social Identities 21 (3): 257-272.

Song, M. 2012. "Making Sense of 'Mixture': States and the Classification of 'Mixed' People." Ethnic and Racial Studies 35 (4): 565-573.

Song, M. 2017. "Generational change and how we conceptualize and measure multiracial people and 'mixture'." Ethnic and Racial Studies. Symposium: International Perspectives on the Measurement of Race and Ethnicity.

Van Ngyuen, D. 2017. “They Called Her a $\mathrm{n}^{\star * *}$ er Lover': Ireland's Interracial Couples Interethnic Partners Describe the Glances and Gossip, Abuse and Violence They Face." Irish Times. May 20. https://www.irishtimes.com/life-and-style/people/they-called-her-a-n-er-lover-ireland-sinterracial-couples-1.3087824.

White, D. 2011. "Dan White: Harney Was Right - We Are Closer to Boston than Berlin." Irish Herald. May 24. https://www.herald.ie/opinion/columnists/dan-white/dan-white-harney-wasright-we-are-closer-to-boston-than-berlin-27980646.html. 